\title{
Gorontalo
}

\section{Manajement Research}

Vol. 2 No. 2 Oktober 2019

P-ISSN: 2614-5197, E-ISSN: 2614-5189

\section{MODEL OF STUDENT TRUST}

\section{MODEL KEPERCAYAAN MAHASISWA}

\author{
Mohamad Afan Suyanto', Sasmita R. Setiawan' \\ Fakultas Ekonomi, Universtas Gorontalo ${ }^{1,2}$ \\ email. afansuyanto@gmail.com \\ Sasmitasetiawan286@gmail.com
}

\begin{abstract}
ABSTRAK
Tujuan dari penelitian ini adalah untuk menganalisis pengaruh (1) kualitas pelayanan terhadap citra institusi pada Universitas Gorontalo, (2) kualitas pelayanan terhadap kepercayaan mahasiswa pada Universitas Gorontalo, (3) citra institusi terhadap kepercayaan mahasiswa pada Universitas Gorontalo dan 4) kualitas pelayanan terhadap kepercayaan mahasiswa melalui citra institusi pada Universitas Gorontalo.

Pengumpulan data dilakukan dengan metode observasi, wawancara dan kuisioner dengan jumlah sampel adalah 286 responden. Data yang terkumpul diolah dengan menggunakan alat analisis deskriptif dan kuantitatif. Teknik analisa yang dipergunakan untuk menganalisis data adalah analisis SEM (Structural Equation Model).

Hasil penelitian menunjukan bahwa : 1) Terdapat pengaruh positif dan signifikan kualitas pelayanan terhadap citra institusi, 2) Terdapat pengaruh positif dan signifikan kualitas pelayanan terhadap kepercayaan mahasiswa, 3) Terdapat pengaruh positif dan signifikan citra institusi terhadap kepercayaan mahasiswa dan 4) Terdapat pengaruh positif dan signifikan kualitas pelayanan terhadap kepercayaan mahasiswa melalui citra institusi
\end{abstract}

Kata kunci: Kualitas Pelayanan; Citra Institusi; Kepercayaan Mahasiswa

\begin{abstract}
The purpose of this study was to analyze the effect of (1) service quality on the image of institutions at the University of Gorontalo, (2) service quality on student trust at Gorontalo University, (3) institutional image on student trust at Gorontalo University and 4) service quality on students trust through the image of the institution at the University of Gorontalo.

Data collection was carried out by the method of observation, interviews and questionnaires with a total sample of 286 respondents. The collected data is processed using descriptive and quantitative analysis tools. The analysis technique used to analyze data is SEM (Structural Equation Model) analysis.

The results showed that: 1) There is a positive and significant influence on the quality of service on the image of the institution, 2) There is a positive and significant effect on the quality of service on student trust, 3) There is a positive and significant effect on the image of the institution on student trust and 4) There is a positive and significant quality of service to student trust through the image of the institution
\end{abstract}

Keyword: Service Quality; Institusional Image; Student Trust 
P-ISSN : 2614-5189, E-ISSN : 2614-5197

\section{PENDAHULUAN}

Kepercayaan dalam pemasaran jasa lebih menekankan pada sikap individu yang mengacu keyakinan konsumen atas kualitas dan keterandalan jasa yang diterimanya. Semakin kuat kepercayaan pelanggan terhadap penyedia jasa, maka selain memperkuat dorongan atau motivasi untuk mempertahankan hubungan, juga memperkuat kecenderungan untuk melakukan pembelian ulang atau sikap positif terhadap perusahaan (Suyanto, Modding, Bima, \& Hasan, 2017).

Pengorbanan yang dikeluarkan oleh mahasiswa merupakan suatu opportunity cost. Pengorbanan itu berupa biaya kuliah, jerih payah dan waktu yang dihabiskan selama mengikuti pendidikan. Manfaat prospektif yang dapat diterima harus lebih besar dari apabila faktor itu digunakan pada kegiatan lain, misalnya pada usaha bisnis. Jika manfaat yang diterima lebih kecil dari manfaat yang dapat diterima pada kegiatan lain, maka kegiatan mengikuti pendidikan di perguruan tinggi dipandang marginal/tidak menjanjikan (Bachmid, 2016)

Fenomena yang terjadi adalah perguruan tinggi kadang kurang memperhatikan aspek kepercayaan mahasiswa seperti sering terjadi keluhan mahasiswa terhadap perubahan jadwal perkuliahan, keterampilan dosen dalam mengajar, pelayananan tenaga penunjang akademik, fasilitas penunjang kegiatan akademik maupun non akademik dan nilai akreditas (prodi dan institusi)

Berbagai strategi dan penelitian dilakukan untuk meningkatkan kepercayaan konsumen seperti penelitian yang lakukan oleh (Leonnard, Daryanto, Sukandar, \& Yusuf, 2014) dalam hasil penelitiannya menyatakan bahwa Kualitas layanan, citra institusi dan biaya memiliki dampak yang signifikan terhadap kepuasan dan kepuasan memiliki pengaruh yang signifikan pada kepercayaan. Namun kualitas pelayanan, citra institusi dan biaya tidak berpengaruh signifikan terhadap kepercayaan. Dari hasil penelitian tersebut dapat diambil kesimpulan bawah kualitas pelayanan, Citra institusi dan biaya memiliki pengaruh tidak langsung terhadap kepercayaan melalui kepuasan sedangkan secara langsung tidak memiliki pengaruh yang sinifikan.

Kemudian (Heri, 2017) dalam temuan penelitiannya menyatakan bahwa peningkatan kualitas layanan tidak secara langsung mempengaruhi kepercayaan pelanggan dan dimediasi oleh citra perusahaan, nilai pelanggan dan kepuasan; kualitas pelayanan berpengaruh terhadap nilai pelanggan dan kepuasan; Selanjutnya, nilai pelanggan dan kepuasan pelanggan berpengaruh terhadap kepercayaan pelanggan sekaligus Hal itu juga membuktikan bahwa kepuasan pelanggan memediasi hubungan antara citra perusahaan terhadap kepercayaan pelanggan dan nilai pelanggan terhadap kepercayaan pelanggan.

Penelitian sebelumnya yang berkaitan dengan kepercayaan memiliki ketidak konsistenan hasil, sehingga hal tersebut memotivasi peneliti untuk melakukan penelitian sejenis untuk mendapatkan temuan mengenai model kepercayaan mahasiswa pada Universitas Gorontalo. 
Dari uraian tersebut yang menjadi masalah dalam penelitian ini adalah : 1) Bagaimana pengaruh kualitas pelayanan terhadap citra institusi pada Universitas Gorontalo; 2) Bagaimana pengaruh kualitas pelayanan terhadap kepercayaan mahasiswa pada Universitas Gorontalo; 3) Bagaimana pengaruh citra institusi terhadap kepercayaan mahasiswa pada Universitas Gorontalo; 4) Bagaimana pengaruh kualitas pelayanan terhadap kepercayaan mahasiswa melalui citra institusi pada Universitas Gorontalo.

\section{LANDASAN TEORI DAN PENGEMBANGAN HIPOTESIS Kualitas Pelayanan}

Kualitas pelayanan adalah kemampuan perusahaan dalam memberikan dan memuaskan kebutuhan konsumen. Hal ini sesuai yang dijelaskan oleh (Kotler \& Keller, 2012) bahwa kualitas adalah totalitas fitur dan karakteristik produk atau jasa yang bergantung pada kemampuannya untuk memuaskan kebutuhan yang dinyatakan atau tersirat. Hal yang berbeda diungkap oleh (Suratno \& Purnama, 2004) dalam penelitiannya memfokuskan kualitas layanan yaitu nilai-nilai yang dianut dan menjadi acuan agar dapat memberi layanan terbaik adalah: profesionalisme yang meliputi integritas, disiplin, kompetensi, transparansi, akuntabilitas, meritokrasi, kemandirian, pelayanan prima serta pembelajaran dan pemberdayaan.

Kemudian masih penjelasan (Kotler \& Keller, 2012), menyatakan bahwa konsumen menciptakan harapan-harapan jasa dari pengalaman masa lalu, komunikasi word of mouth, dan iklan. Konsumen membandingkan jasa yang dipersepsikan dan yang diharapkan. Setiap penelitian akademis yang dilakukan sebelumnya telah mengidentifikasikannya sebagai faktor kualitas jasa dalam menjaga keunggulan persaingan dan pengaruhnya dalam mempertahankan hubungan dengan konsumen.

Dalam penelitian Parasuraman et al. digunakan Model Konseptual SERVQUAL untuk mengidentifikasi 5 (lima) macam kesenjangan (gap) kualitas jasa yang memungkinkan kegagalan penyampaian jasa (Kotler \& Keller, 2012). Hasil penelitiannya menunjukan bahwa terdapat lima kesenjangan antara harapan konsumen dengan persepsi manajemen atas harapan tersebut. Atribut kehandalan merupakan dimensi dengan peringkat tertinggi dibandingkan dengan atribut lainnya. Artinya, pada penelitian tersebut menunjukan bahwa atribut kehandalan merupakan dimensi yang paling dominan atas keseluruhan persepsi harapan konsumen terhadap kinerja masing-masing perusahaan dalam hal ini kualitas jasa (jasa yang dirasakan).

\section{Citra Institusi}

Konsumen menilai bahwa citra sebuah organisasi sangat berpengaruh terhadap tercapainya misi dan visi organisasi. Kepercayaan dan pengakuan atau pandangan positif atas pelayanan yang diberikan akan tumbuh sejalan dengan citra yang baik.

Menurut (Kotler \& Keller, 2012), pengertian citra adalah kepercayaan, ide, dan impressi seseorang terhadap sesuatu, image merupakan kesan, impressi, perasaan 
atau persepsi yang ada pada publik mengenai perusahaan, suatu obyek, orang atau lembaga. Bagi perusahaan, citra berarti persepsi masyarakat terhadap jati diri perusahaan. Persepsi ini didasarkan pada apa yang masyarakat ketahui atau yang masyarakat kira tentang perusahaan yang bersangkutan. Oleh karena itulah perusahaan yang sama belum tentu memiliki citra yang sama pula dihadapan orang. Citra perusahaan menjadi salah satu pegangan bagi konsumen dalam mengambil keputusan penting. Citra yang baik akan menimbulkan dampak positif bagi perusahaan, sedangkan citra yang buruk melahirkan dampak negatif dan melemahkan kemampuan perusahaan dalam persaingan.

Citra adalah persepsi masyarakat terhadap perusahaan atau produknya. Ctra dipengaruhi oleh banyak faktor yang diluar kontrol perusahaan. Citra yang efektif melakukan 3 hal, antara lain:

a. Memantapkan karakter produk dan usulan nilai

b. Menyampaikan karakter itu dengan cara yang berbeda sehingga tidak dikacaukan dengan karakter pesaing

c. Memberikan kekuatan emosional yang lebih dari sekedar citra mental

\section{Konsep Kepercayaan Mahasiswa}

Andaleeb dalam Mendez dalam (Suyanto et al., 2017) menjelaskan pada bidang pendidikan, kepercayaan mahasiswa dapat dipahami sebagai kepercayaan mahasiswa terhadap integritas dan keandalan universitas. Kepercayaan mahasiswa dikembangkan melalui pengalaman pribadi dengan karyawan. Jika sebuah institusi pendidikan ingin membangun hubungan jangka panjang dengan konstituennya, ia harus mengembangkan kepercayaan sebagai bagian dari hubungan. Kurangnya kepercayaan dapat sangat merusak hubungan jangka panjang.

Robbins dan Judge dalam (Leonnard et al., 2014) menyebutkan empat dimensi kunci darikonsep kepercayaan, sebagai berikut:

1. Integritas, yang mengacu pada kejujuran dan kebenaran

2. Kompetensi, yang berhubungan dengan pengetahuan, keterampilan teknis dan interpersonal yang dimiliki oleh seorang individu

3. Konsistensi, berkaitan dengan keandalan, kemampuan memprediksi dan evaluasi individu dalam menangani situasi tertentu

4. Keterbukaan, yang mengacu pada tiga aspek komunikasi interpersonal, yaitu: kesediaan untuk mengungkapkan diri, selama informasi itu memadai; kesediaan untuk jujur terhadap pendapat seseorang; memiliki perasaan dan pikiran

\section{Pengembangan Hipotesis \\ Pengaruh Kualitas Pelayanan Terhadap Citra Institusi}

Hasil penelitian dari (Quoquab, Bashiruddin, \& Abdul Rasid, 2013), (Kusumawati, 2013), (Kurniawan \& Sidharta, 2016) dan (Suyanto, Usu, \& Moodoeto, 2019) menyatakan bahwa pengaruh yang terjadi antara variabel laten kualitas pelayanan dan variabel laten citra institusi signifikan.

Berdasarkan penelitian-penelitian di atas dapat dirumuskan hipotesis:

$\mathrm{H} 1$ : kualitas pelayanan memengaruhi citra institusi. 
P-ISSN : 2614-5189, E-ISSN : 2614-5197

\section{Pengaruh Kualitas Pelayanan Terhadap Kepercayaan Mahasiswa}

Hasil penelitian (Quoquab et al., 2013), (Rahmani-Nejad, Firoozbakht, \& Taghipoor, 2014), (Elrado, Kumadji, \& Yulianto, 2014) dan (Sutrisno, Brahmasari, \& Panjaitan, 2016) mengungkapkan bahwa kualitas layanan yang diberikan akan meningkatkan kepercayaan konsumen.

Berdasarkan penelitian-penelitian di atas dapat dirumuskan hipotesis:

H2: kualitas pelayanan memengaruhi kepercayaan mahasiswa.

\section{Pengaruh Citra Institusi Terhadap Kepercayaan Mahasiswa}

Hasil penelitian dari (Hermawan, Hadiwidjojo, Rofiaty, \& Solimun, 2014) dan (Sutrisno et al., 2016) menyatakan bahwa citra memiliki pengaruh positif terhadap kepercayaan mahasiswa.

Berdasarkan penelitian-penelitian di atas dapat dirumuskan hipotesis:

H3: citra institusi memengaruhi kepercayaan mahasiswa.

\section{Pengaruh Kualitas Pelayanan Terhadap Kepercayaan Melaui Citra Sebagai Variabel Intervening}

Hasil penelitian (Heri, 2017) dalam temuan penelitiannya menyatakan bahwa peningkatan kualitas layanan tidak secara langsung mempengaruhi kepercayaan pelanggan namun dimediasi oleh citra perusahaan, nilai pelanggan dan kepuasan;

Berdasarkan penelitian di atas dapat dirumuskan hipotesis:

$\mathrm{H} 4$ : kualitas pelayanan memengaruhi kepercayaan mahasiswa melalui mediasi citra institusi.

\section{METODE PENELITIAN}

Jenis Penelitian

Studi ini menggunakan penelitian penjelasan (explanatory research). Menurut (Singarimbun \& Effendi, 2006), explanatory research adalah penelitian yang menjelaskan hubungan kausal antara variabel- variabel melalui pengajuan hipotesis dengan menggunakan data-data yang sama.

\section{Populasi Dan Sampel}

Populasi adalah wilayah generalisasi yang terdiri atas subyek/obyek yang mempunyai kualitas dan karakteristik tertentu yang ditetapkan oleh peneliti untuk dipelajari dan kemudian ditarik kesimpulannya (Sugiyono, 2011: 61).

Dalam setiap penelitian, populasi yang dipilih erat kaitannya dengan masalah yang ingin dipelajari. Populasi dalam penelitian ini adalah seluruh Mahasiswa di Univeristas Gorontalo berjumlah3.788 orang.

Pengambilan sampel dalam penelitian ini dilakukan secara sampel representatif, yang akan memberikan hasil yang mempunyai kemampuan untuk digeneralisasi. Kriteria sampel yang representatif tergantung pada aspek yang saling berkaitan yaitu akurasi sampel dan keakuratan (presisi) sampel. Berkaitan dengan hal tersebut maka dalam penelitian ini menggunakan pendekatan probability sampling yaitu menetapkan sampel yang dilakukan secara random atau acak. 
Kelloway dan Marsh et. al., menjelaskan ukuran sampel untuk model persamaan struktural (SEM) paling sedikit adalah 200 pengamatan (Riduwan \& Kuncoro, 2008). Selain itu, Joreskog dan Sorbom menyatakan bahwa hubungan antara banyaknya variabel dan ukuran sampel minimal dalam model persamaan struktural dapat dilihat pada tabel 1 berikut ini.

Tabel 1. Ukuran Sampel Minimal dan Jumlah Variabel

\begin{tabular}{cc}
\hline Jumlah Variabel & Ukuran Sampel Minimal \\
\hline $\mathbf{3}$ & 200 \\
\hline $\mathbf{5}$ & 200 \\
$\mathbf{1 0}$ & 200 \\
\hline $\mathbf{1 5}$ & 360 \\
$\mathbf{2 0}$ & 630 \\
\hline $\mathbf{2 5}$ & 975 \\
\hline $\mathbf{3 0}$ & 1395
\end{tabular}

Sumber: (Riduwan dan Kuncoro, 2008)

Dengan demikian sampel dalam penelitian ini adalah 289 responden.

\section{Analisis Data}

Model yang digunakan dalam penelitian ini adalah model persamaan struktural atau structural equation modeling (SEM) untuk mengetahui hubungan kausal antar variabel laten yang terdapat dalam persamaan struktural.

Untuk menganalisis data hasil survei, menginterpretasi hasil penelitian serta untuk menguji hipotesis, maka digunakan analisis deskriptif, pengujian model pengukuran, pengujian model overal, pengujian model struktural serta pengujian hubungan variabel terobservasi. Untuk memudahkan proses analisis digunakan beberapa program aplikasi statistik, antara lain SPSS ( Statistical Package for Service Solution) dan LISREL yang merupakan paket dalam program SEM (Structural Equation Model).

\section{Analisis Deskriptif}

Tujuan analisis deskriptif adalah untuk menjelaskan atau mendiskripsikan karakteristik responden maupun variabel yang diteliti. Bentuknya tergantung dari jenis data. Untuk data kategorik hanya dapat menjelaskan angka/nilai jumlah dan persentase masing-masing kelompok, sedangkan data numerik digunakan nilai mean (rata-rata), median, standar deviasi, dsb.

\section{Pengujian model pengukuran}


P-ISSN : 2614-5189, E-ISSN : 2614-5197

Pengujian model pengukuran dilakukan untuk mengetahhui apakah model pengukuran tersebut compatible atau tidak untuk digunakan. Oleh karena itu dalam pengujian digunakan metode confirmatory faktor análisis (CFA) yang terbagi menjadi dua, masing-masing uji goodness of fit dan uji validitas yang selanjutnya dilakukan uji reliabilitas, uji normalitas dan uji outliners.

\section{HASIL ANALISIS DAN PEMBAHASAN}

\section{Analisis Hasil Penelitian}

\section{a. Pengujian Model SEM secara Keseluruhan}

Output Lisrel untuk ukuran-ukuran absolute fit measures, incremental fit measures dan parsimony fit measures. Ukuran-ukuran tersebut berfungsi untuk pengujian model SEM secara keseluruhan. Adapun ringkasan pengujian model SEM secara keseluruhan adalah sebagai berikut:

Tabel 1. Evaluasi Goodness of fit index

\begin{tabular}{cccc}
\hline $\begin{array}{c}\text { Goodness of } \\
\text { fit } \text { indeks }\end{array}$ & $\begin{array}{c}\text { Cut-off } \\
\text { Value }\end{array}$ & Hasil & Keterangan \\
\hline$\chi^{2}-$ Chi-square & Diharapkan kecil & 127.31 & Baik \\
\hline Probability Chi-square & $\geq 0,05$ & 0,000 & Marginal \\
\hline RMSEA & $\leq 0,08$ & 0,061 & Baik \\
\hline NFI & $\geq 0,90$ & 0,97 & Baik \\
\hline NNFI & $\geq 0,90$ & 0,98 & Baik \\
\hline CFI & $\geq 0,90$ & 0,98 & Baik \\
\hline IFI & $\geq 0,90$ & 0,98 & Baik \\
\hline RFI & $\geq 0,90$ & 0,96 & Baik \\
\hline RMR & $\leq 0,05$ & 0,017 & Baik \\
\hline SRMR & $\leq 0,05$ & 0,046 & Baik \\
\hline GFI & $\geq 0,90$ & 0,94 & Baik \\
\hline AGFI & $\geq 0,90$ & 0,91 & Baik \\
\hline
\end{tabular}

Sumber : data diolah, 2019

Dari evaluasi model menunjukan dari dua belas kriteria goodness of fit indices hanya satu yang belum memenuhi kriteria yakni probability namun nilainya sudah mendekati nilai kritis. Sehingga dengan demikian dapat disimpulkan bahwa model SEM secara keseluruhan memiliki kemampuan yang baik dalam hal mencocokkan data sampel (good fit). Dengan kata lain, matriks kovarian estimasi model SEM tidak berbeda secara statistik terhadap matriks kovarian data sampel.

b. Pengujian Model Pengukuran dengan Confirmatory Factor Analysis (CFA)

Berdasarkan pengujian model SEM secara keseluruhan (overall), diketahui model SEM memiliki kemampuan yang baik dalam hal mencocokkan data (good fit). Selanjutnya akan dilakukan pengujian model pengukuran dengan teknik statistik confirmatory factor analysis (CFA), Hasil akhir CFA diperoleh 
melalui uji kecocokan keseluruhan model, analisis validitas dan reliabilitas model (Wijanto, 2008).

\section{Analisis Validitas Model Pengukuran}

Pengujian validitas ini menggunakan program Structural Equation Modeling LISREL 8.70. Sifat convergent validity yang baik ditunjukkan dengan nilai standardized loading factor (SLF) yang tinggi. hal ini sesuai dengan penjelasan (Hair, Black, Babin, \& Anderson, 2010) menyarankan nilai $\mathrm{SLF} \geq 0,5$ menunjukkan sifat convergent validity yang baik telah dicapai atau lebih diharapkan SLF $\geq 0,7$.pada gambar dan tabel berikut ini merupakan output Lisrel yang menyajikan nilai-SLF untuk masing-masing variabel indikator atau manifes.

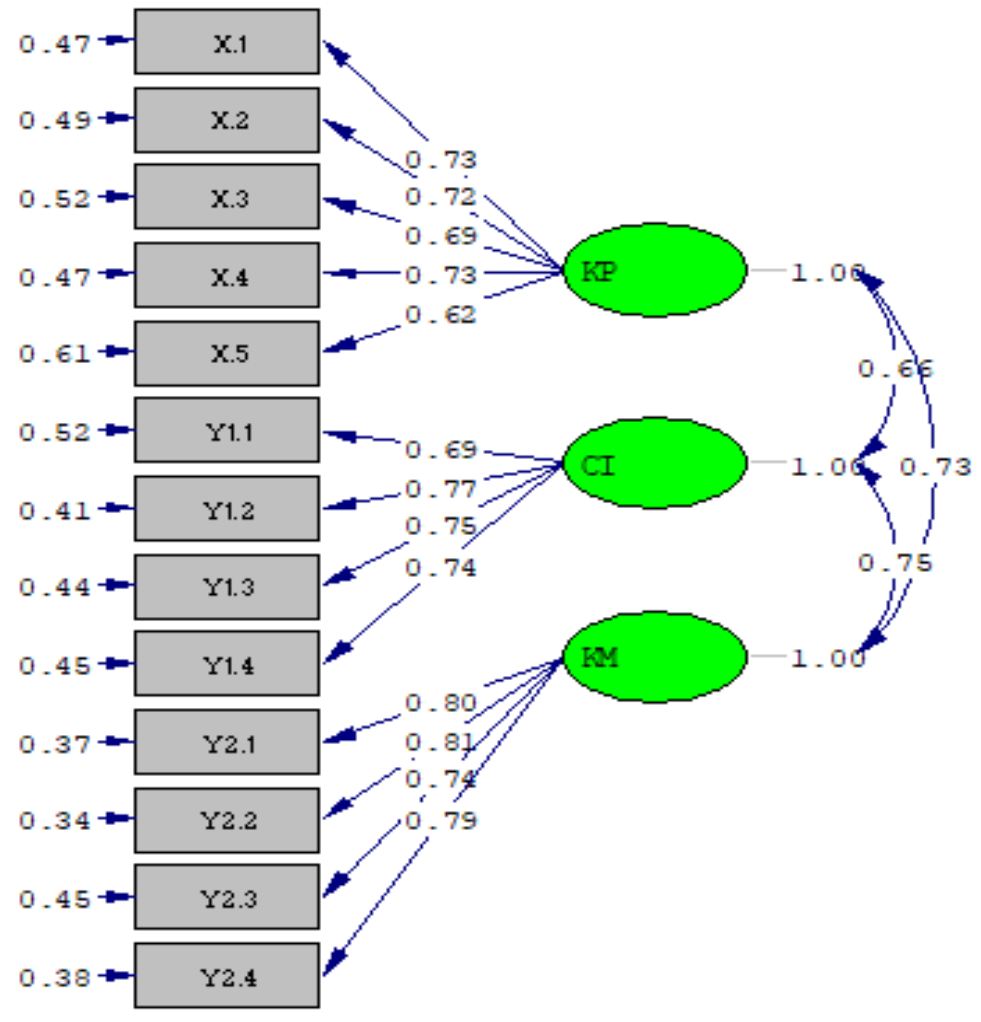

Chi-Square $=127.31, \mathrm{df}=62, \mathrm{P}-\mathrm{value}=0.00000, \mathrm{RMSEA}=0.061$

Gambar 1. Model Standardized Solution 
P-ISSN : 2614-5189, E-ISSN : 2614-5197

Untuk lebih menjelaskan gambar model Standardized Solution maka digambarkan pada tabel berikut ini:

Tabel 2. Nilai Standardized Loading Factor (SLF)

\begin{tabular}{ccc}
\hline Kode Indikator & $\begin{array}{c}\text { Standardized Loading } \\
\text { Factors } \\
\text { (SLF) } \geq 0,50\end{array}$ & Keterangan \\
\hline $\mathbf{X 1 . 1}$ & 0,73 & Valid \\
\hline $\mathbf{X 1 . 2}$ & 0,72 & Valid \\
\hline $\mathbf{X 1 . 3}$ & 0,69 & Valid \\
\hline $\mathbf{X 1 . 4}$ & 0,73 & Valid \\
\hline $\mathbf{X 1 . 5}$ & 0,62 & Valid \\
\hline Y1.1 & 0,69 & Valid \\
\hline Y1.2 & 0,77 & Valid \\
\hline Y1.3 & 0,75 & Valid \\
\hline Y1.4 & 0,74 & Valid \\
\hline Y2.1 & 0,80 & Valid \\
\hline Y2.2 & 0,81 & Valid \\
\hline Y2.3 & 0,74 & Valid \\
\hline Y2.4 & 0,79 & Valid \\
\hline
\end{tabular}

Sumber: data diolah, 2019

Berdasarkan output Lisrel pada tabel 26 dapat dilihat bahwa seluruh indikator variabel kualitas pelayanan, citra institusi, nilai yang dirasakan, kepuasan dan kepercayaan mahasiswa memiliki nilai $\mathrm{SLF} \geq 0,50$. Hal ini menunjukkan bahwa sifat convergent validity yang baik telah dicapai dari sisi ukuran SLF.

\section{Analisis Reliabilitas Model Pengukuran}

Uji reliabilitas menunjukkan sejauh mana suatu alat ukur yang dapat memberikan hasil yang relative sama apabila dilakukan pengukuran kembali pada obyek yang sama. Reliabilitas dihitung dengan formula Variance Extract dan Contruct Reliability dengan rumus sebagai berikut:

Rumus CR

Constuct Reliabily $=\frac{\left(\sum \text { Standardized Loading }\right)^{2}}{\left(\sum \text { Standardized Loading }\right)^{2}+\left(\sum \text { Measurement Error }\right)}$

Rumus VE

Variance Extracted $=\frac{\sum \text { Standardized Loading }{ }^{2}}{\sum \text { Standardized Loading }{ }^{2}+\sum \text { Measurement Error }}$ 
Semakin besar nilai ini, menunjukkan bahwa indikator-indikator penyusun bagi suatu peubah laten merupakan indikator-indikator yang handal dalam mengukur peubah laten tersebut. Nilai kehandalan konstruk yang disarankan adalah lebih besar dari 0,7. Sedangkan ukuran kelayakan variance extracted yang disarankan adalah lebih besar dari 0,5. berikut ini:

Untuk melihat hasil perhitungan CR dan VE dapat dilihat pada table

Tabel 3. Reliabilitas Konstruk

\begin{tabular}{|c|c|c|c|c|c|}
\hline $\begin{array}{l}\text { Variabel } \\
\text { Indikator }\end{array}$ & SLF & Error & $\mathrm{SLF}^{2}$ & CR & VE \\
\hline $\mathrm{X} 1.1$ & 0,73 & 0,16 & 0,53 & \multirow{6}{*}{0,93} & \multirow{6}{*}{0,73} \\
\hline $\mathrm{X} 1.2$ & 0,72 & 0,19 & 0,52 & & \\
\hline $\mathrm{X} 1.3$ & 0,69 & 0,21 & 0,48 & & \\
\hline $\mathrm{X} 1.4$ & 0,73 & 0,15 & 0,53 & & \\
\hline $\mathrm{X} 1.5$ & 0,62 & 0,2 & 0,38 & & \\
\hline Total & 3,49 & 0,91 & 2,44 & & \\
\hline Y1.1 & 0,69 & 0,19 & 0,48 & \multirow{5}{*}{0,92} & \multirow{5}{*}{0,75} \\
\hline Y1.2 & 0,77 & 0,15 & 0,59 & & \\
\hline Y1.3 & 0,75 & 0,15 & 0,56 & & \\
\hline Y1.4 & 0,74 & 0,22 & 0,55 & & \\
\hline Total & 2,95 & 0,71 & 2,18 & & \\
\hline Y2.1 & 0,8 & 0,16 & 0,64 & \multirow{5}{*}{0,94} & \multirow{5}{*}{0,79} \\
\hline Y2.2 & 0,81 & 0,14 & 0,66 & & \\
\hline Y2.3 & 0,74 & 0,19 & 0,55 & & \\
\hline Y2.4 & 0,79 & 0,16 & 0,62 & & \\
\hline Total & 3,14 & 0,65 & 2,47 & & \\
\hline
\end{tabular}

Sumber: data diolah, 2019

Berdasarkan Tabel 27, nilai CR untuk masing-masing variabel laten yaitu variabel kualitas pelayanan sebesar 0,93, variabel citra institusi 0,92, dan variabel kepercayaan mahasiswa sebesar 0,94. Nilai CR masing-masing variabel laten tersebut $\geq 0,7$. Dalam hal ini sesuai dengan penjelasan (Hair et al., 2010) menyatakan nilai CR $\geq 0,7$ termasuk good reliability. Kemudian nilai VE untuk masing-masing variabel laten yaitu variabel kualitas pelayanan sebesar 0,73 , variabel citra institusi 0,75 , dan variabel kepercayaan mahasiswa sebesar 0,79. Seluruh variabel laten memiliki nilai $\mathrm{VE} \geq 0,5$. nilai $\mathrm{VE} \geq 0,5$ menunjukkan adequate convergence (Hair et al., 2010). 
Berdasarkan hasil tersebut bahwa ketiga ukuran, yakni SLF, CR, dan VE memenuhi good rule of thumb, maka sifat convergent validity dapat dikatakan telah dicapai dengan baik.

\section{Pengujian Model Struktural}

Sebelumnya telah dilakukan pengujian model SEM secara keseluruhan dan pengujian model pengukuran. Hasil dari kedua pengujian tersebut menunjukkan hasil yang baik. Pada pengujian model SEM secara keseluruhan menunjukkan hasil bahwa model SEM secara keseluruhan sudah mampu untuk mencocokkan/fit data (good fit). Sedangkan pada pengujian model pengukuran menunjukkan hasil bahwa model pengukuran memiliki sifat convergent validity dan discriminant validity yang baik. Selanjutnya akan dilakukan dengan pengujian model struktural. Perhatikan output Lisrel berikut ini (Gambar 8).

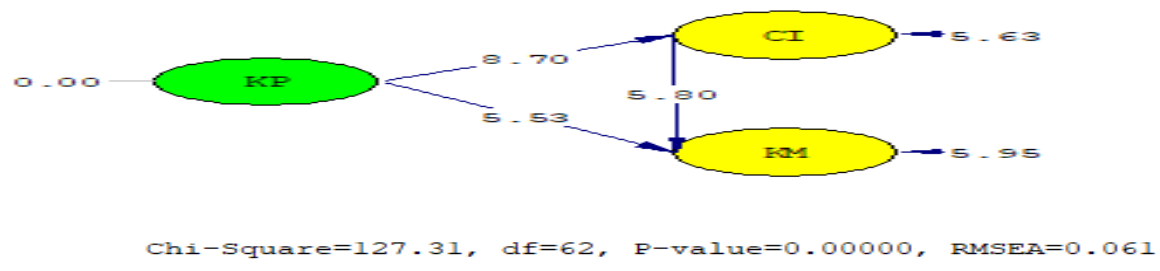

\section{Pengujian Hipotesis}

\section{Gambar 2 Model Struktur}

Selanjutnya untuk mengevaluasi setiap konstruk terhadap pengaruh langsung adalah koefisien dari semua garis koefisien dengan anak panah satu ujung, sedangkan efek tidak langsung adalah efek yang muncul melalui variabel antara (intervening variable) dan efek total adalah efek dari berbagai hubungan (Ferdinand, 2016), yang hasil uji disajikan sebagai berikut :

Tabel 4. Pengujian Hipotesis

\begin{tabular}{cccccccc}
\hline & Variable & & \multicolumn{2}{c}{ Standardized Effect } & $\begin{array}{c}\mathrm{t} \\
\text { hitun } \\
\mathrm{g}\end{array}$ & Ket. \\
\hline Endogen & $\begin{array}{c}\text { Interveni } \\
n g\end{array}$ & Eksogen & Direct & $\begin{array}{c}\text { Indirec } \\
t\end{array}$ & Total & & \\
\hline $\begin{array}{c}\text { Kualitas } \\
\text { Pelayana } \\
\mathrm{n}\end{array}$ & - & Citra & 0,66 & - & 0,66 & 8,70 & $\begin{array}{c}\text { Positif } \\
\text { Signifik } \\
\text { an }\end{array}$ \\
\hline $\begin{array}{c}\text { Kualitas } \\
\text { Pelayana } \\
\text { n }\end{array}$ & - & $\begin{array}{c}\text { Kepercaya } \\
\text { an }\end{array}$ & 0,73 & - & 0,73 & 5,53 & $\begin{array}{c}\text { Positif } \\
\text { Signifik } \\
\text { an }\end{array}$ \\
\hline $\begin{array}{c}\text { Citra } \\
\text { Institusi }\end{array}$ & - & $\begin{array}{c}\text { Kahasiswa } \\
\text { Kepercaya } \\
\text { n }\end{array}$ & 0,47 & - & 0,47 & 5,80 & $\begin{array}{c}\text { Positif } \\
\text { Signifik }\end{array}$ \\
\hline
\end{tabular}


P-ISSN : 2614-5189, E-ISSN : 2614-5197

\begin{tabular}{|c|c|c|c|c|c|c|c|}
\hline & & Mahasiswa & & & & & an \\
\hline $\begin{array}{c}\text { Kualitas } \\
\text { Pelayana } \\
\mathrm{n}\end{array}$ & $\begin{array}{c}\text { Citra } \\
\text { Institusi }\end{array}$ & $\begin{array}{c}\text { Kepercaya } \\
\text { an } \\
\text { Mahasiswa }\end{array}$ & 0,73 & 0,31 & 1,04 & 5,51 & $\begin{array}{c}\text { Positif } \\
\text { Signifik } \\
\text { an }\end{array}$ \\
\hline
\end{tabular}

Sumber: data diolah, 2019

Adapun interpretasi dari tabel 28 adalah sebagai berikut :

1. Kualitas pelayanan berpengaruh positif dan signifikan terhadap citra institusi dengan nilai koefisien 0,66. Nilai koefisien jalur yang positif menunjukkan bahwa variabel laten kualitas pelayanan berpengaruh positif terhadap citra institusi dengan nilait hitung $=8,70>t_{\text {tabel }}=1,96$, maka disimpulkan bahwa pengaruh yang terjadi antara variabel laten kualitas pelayanan dan variabel laten citra institusi signifikan. Dengan demikian hipotesis diterima.

Hasil pengujian ini menunjukan bahwa semakin baik kualitas pelayanan diberikan perguruan tinggi swasta maka semakin meningkat citra institusi secara signifikan.

2. Kualitas pelayanan berpengaruh positif dan signifikan terhadap kepercayaan dengan nilai koefisien 0,73. Nilai koefisien jalur yang positif menunjukkan bahwa variabel laten kualitas pelayanan berpengaruh positif terhadap kepercayaan mahasiswa dengan nilait $_{\text {hitung }}=5,53>t_{\text {tabel }}=1,96$, maka disimpulkan bahwa pengaruh yang terjadi antara variabel laten kualitas pelayanan dan variabel laten kepercayaan mahasiswa signifikan. Dengan demikian hipotesis diterima.

Hasil pengujian ini menunjukan bahwa semakin baik kualitas pelayanan diberikan perguruan tinggi swasta maka semakin meningkat kepercayaan mahasiswa secara signifikan.

3. Citra institusi berpengaruh positif dan signifikan terhadap kepercayaan mahasiswa dengan nilai koefisien 0,47. Nilai koefisien jalur yang positif menunjukkan bahwa variabel laten citra institusi berpengaruh positif terhadap kepercayaan mahasiswa dengan nilait $_{\text {hitung }}=5,80>t_{\text {tabel }}=1,96$, maka disimpulkan bahwa pengaruh yang terjadi antara variabel laten citra institusi dan variabel kepercayaan mahasiswa signifikan. Dengan demikian hipotesis diterima.

Hasil pengujian ini menunjukan bahwa semakin baik citra institusi yang dimiliki maka kepercayaan mahasiswa semakin meningkat secara signifikan.

4. Kualitas pelayanan berpengaruh positif dan signifikan terhadap kepercayaan mahasiswa melalui citra institusi dengan nilai koefisien sebesar 1,04. Nilai koefisien jalur yang positif menunjukkan bahwa variabel laten kualitas pelayanan berpengaruh positif terhadap 
kepercayaan mahasiswa melalui citra institusi dan nilait hitung $=5,51>$ $t_{\text {tabel }}=1,96$, maka disimpulkan bahwa pengaruh yang terjadi antara variabel laten kualitas pelayanan dan variabel laten kepercayaan mahasiswa melalui citra institusi signifikan. Dengan demikian maka hipotesis diterima.

Hasil pengujian ini menunjukan bahwa semakin baik kualitas pelayanan yang diberikan maka kepercayaan mahasiswa akan meningkat secara positif namun signifikan melaui citra institusi.

\section{Pembahasan}

\section{Pengaruh Kualitas Pelayanan Terhadap Citra Institusi}

Hasil penelitian ini menunjukan bahwa terdapat pengaruh yang positif dan signifikan kualitas pelayanan terhadap citra institusi, hasil penelitian ini sejalan dengan temuan penelitian (Quoquab et al., 2013), (Kusumawati, 2013) dan (Suyanto et al., 2019) menyatakan bahwa pengaruh yang terjadi antara variabel laten kualitas pelayanan dan variabel laten citra institusi signifikan.

\section{Pengaruh Kualitas Pelayanan Terhadap Kepercayaan Mahasiswa}

Hasil penelitian ini menunjukan bahwa terdapat pengaruh yang positif dan signifikan kualitas pelayanan terhadap kepercayaan mahasiswa, hasil penelitian ini sejalan dengan temuan penelitian (Quoquab et al., 2013), (Rahmani-Nejad et al., 2014), (Elrado et al., 2014), (Sutrisno et al., 2016) dan (Suyanto et al., 2017) mengungkapkan bahwa kualitas layanan yang diberikan akan meningkatkan kepercayaan.

\section{Pengaruh Citra Institusi Terhadap Kepercayaan Mahasiswa}

Hasil penelitian ini menunjukan bahwa terdapat pengaruh yang positif dan signifikan citra institusi terhadap kepercayaan mahasiswa, hasil penelitian ini sejalan dengan temuan dari (Hermawan et al., 2014) dan (Sutrisno et al., 2016) menyatakan bahwa citra memiliki pengaruh positif terhadap kepercayaan mahasiswa.

Pengaruh Kualitas Pelayanan Terhadap Kepercayaan Melaui Citra Sebagai Variabel Intervening

Hasil penelitian ini menunjukan bahwa terdapat pengaruh yang positif dan signifikan kualitas pelayanan terhadap kepercayaan mahasiswa melaui citra institusi, hasil penelitian ini sejalan dengan temuan penelitian (Heri, 2017) yang menyatakan bahwa peningkatan kualitas layanan tidak secara langsung mempengaruhi kepercayaan pelanggan namun dimediasi oleh citra perusahaan, nilai pelanggan dan kepuasan;

\section{PENUTUP}

Berdasarkan hasil penelitian yang telah dicapai maka dapat diuraikan kesimpulan sebagai berikut:

Terdapat pengaruh positif dan signifikan kualitas pelayanan terhadap citra institusi

Terdapat pengaruh positif dan signifikan kualitas pelayanan terhadap 
P-ISSN : 2614-5189, E-ISSN : 2614-5197

kepercayaan mahasiswa

Terdapat pengaruh positif dan signifikan citra institusi terhadap kepercayaan mahasiswa

Terdapat pengaruh positif dan signifikan kualitas pelayanan terhadap kepercayaan mahasiswa melalui citra institusi sebagai variable antara

\section{DAFTAR PUSTAKA}

Bachmid, S. (2016). Pengaruh Berbagai Dimensi Kualitas Layanan Terhadap Kepuasan Mahasiswa Dan Alasan Memilih Perguruan Tinggi Di Kota Palu. Makassar.

Elrado, M., Kumadji, S., \& Yulianto, E. (2014). Pengaruh Kualitas Pelayanan Terhadap Kepuasan, Kepercayaan dan Loyalitas. Jurnal Administrasi Bisnis.

Ferdinand, P. D. A. (2016). Metode Penelitian Manajemen: Pedoman Penelitian untuk Skripsi, Tesis dan Disertasi Ilmu Manajemen. In BP Undip 2. https://doi.org/10.4304/jcp.8.2.326-333

Hair, J., Black, W., Babin, B., \& Anderson, R. (2010). Multivariate Data Analysis: A Global Perspective. In Multivariate Data Analysis: A Global Perspective. New Jersey: Pearson Prentice Hall.

Heri, H. (2017). Analysis the Effect of Service Quality, Customers Value, Customer Satisfaction and Customer Trust on Corporate Image. IOSR Journal of Business and Management, 19(06), 38-46. https://doi.org/10.9790/487X-1906013846

Hermawan, D., Hadiwidjojo, D., Rofiaty, \& Solimun. (2014). Higher Education Image and Cost: The Effects and Impacts on Student Satisfaction and Trust ( A Study On Private University Students Majoring In Ict In Indonesia ). Journal of Economic Practices and Theories, 4(4).

Kotler, P., \& Keller, K. L. (2012). Marketing Management (14th ed.). London: Pearson Education, Inc.

Kurniawan, P., \& Sidharta, I. (2016). SERVQUAL on brand image and relationship equity. International Review of Management and Marketing, 6(4), 866-871.

Kusumawati, S. N. S. K. A. (2013). Pengaruh Kualitas Pelayanan Terhadap Kepuasan Pelanggan, Citra Perusahaan Dan Loyalitas Pelanggan Survei Padatamu Pelanggan Yang Menginap Di Hotel Pelangi Malang. Fakultas Ilmu Administrasi Universitas Brawijaya, 6(2), 1-9.

Leonnard, Daryanto, H. K. S., Sukandar, D., \& Yusuf, E. Z. (2014). The Loyalty Model 
P-ISSN : 2614-5189, E-ISSN : 2614-5197

of Private University Student. International Research Journal of Business Studies, $7(1), 55-68$.

Quoquab, F., Bashiruddin, R., \& Abdul Rasid, S. Z. (2013). A structural look at service loyalty: Role of service quality, corporate image, and trust. American Journal of Economics, 3, 177-183.

Rahmani-Nejad, L., Firoozbakht, Z., \& Taghipoor, A. (2014). Service Quality, Relationship Quality and Customer Loyalty (Case Study: Banking Industry in Iran). Open Journal of Social Sciences. https://doi.org/10.4236/jss.2014.24028

Riduwan \& Kuncoro, Engkos Achmad. 2008. Cara Menggunakan dan Memakai Analisis Jalur. Bandung : Alfabeta.

Singarimbun, M., \& Effendi, S. (2006). Metode Penelitian Survei. Jakarta: LP3ES.

Suratno, F. G. S., \& Purnama, N. (2004). Analisis Tingkat Kepuasan Wajib Pajak terhadap Kualitas Layanan Kantor Pelayanan Pajak Yogyakarta Dua. Sinergi. https: / /doi.org/10.20885/sinergi.vol7.iss 1.art5

Sutrisno, Brahmasari, I. A., \& Panjaitan, H. (2016). The Influence of Service Quality, and Customer Relationship Management (CRM) Of Patient Satisfaction, Brand Image, Trust, and Patient Loyalty on Indonesian National Army Level II Hospitals. International Journal of Business and Management Invention ISSN (Online, 5(5), 2319-8028. Retrieved from www.ijbmi.org

Suyanto, M. A., Modding, B., Bima, M. J., \& Hasan, S. (2017). The Effect of the Quality of Service And the Image of the Institution on the Values Received, the Satisfaction of And The Trust of College Students on Private Colleges in the Province of Gorontalo. Journal of Research in Humanities and Social Science, 5(10), 43-50. Retrieved from http://www.questjournals.org/jrhss/papers/vol5issue 10/K5104350.pdf

Suyanto, M. A., Usu, I., \& Moodoeto, M. J. (2019). The Role of Service Quality on Building Student Satisfaction. American Journal of Economics, 9(1), 17-20. https: / /doi.org/10.5923/j.economics.20190901.03

Wijanto, S. . (2008). Structural Equation Modeling Dengan LISREL 8.8.2 Konsep Dan Tutorial. In Structural Equation Modeling Dengan LISREL 8.8.2 Konsep Dan Tutorial. https://doi.org/10.1016/j.ocecoaman.2012.11.005 